\title{
PECULIARITY OF CERTAIN ORGANIC DEPOSITS WITHIN THE FLUVIAL ENVIRONMENT OF THE OULANKA VALLEY, NORTH-EASTERN FINLAND
}

\author{
LEO KOUTANIEMI
}

\begin{abstract}
KOUTANIEMI, LEO 1982: Peculiarity of certain organic deposits within the fluvial environment of the Oulanka valley, northeastern Finland. Bull. Geol. Soc. Finland 54: 1-2, 45-55.

An examination is made of certain organic deposits dating back at least 5000 years according to palynological evidence in existing fluvial sedimentary environments and certain older environments in the Oulanka valley. The sites concerned are described in detail, with their radiocarbon dates and the necessary background of Pleistocene and Early Holocene events. Alternatives for the origins of these deposits are discussed, their special stratigraphical features are described and a possible explanation is put forward for their preservation from fluvial erosion.
\end{abstract}

Leo Koutaniemi, Department of Geography, University of Oulu, SF-90570 Oulu 57, Finland.

\section{History}

By the early 1970's research on the valley of the Oulanka river had revealed the presence of unusual slab-like formations of fine sediments and organic material about a square foot in area each and some $5-10 \mathrm{~cm}$ thick at certain point bars on the lower course of the river. Pollen analyses carried out at once on these deposits obviously derived from some other environment showed a complete absence of spruce (Picea) pollen, suggesting an age of at least 5000 years (see Hicks, 1975, p. 13). The proportions of the main arboreal species, birch and pine, in three of these slabs varied in the range 80.595.5\% Betula and 4-17\% Pinus, with occasional occurrences of Alnus, Corylus, Ulmus and Carpinus. NAP accounted for $29-49 \%$ of the total AP + NAP.

With the continuation of other research in the area, it was then noticed that new slabs of the same kind would appear in the same situations each spring. Their origins remained a mystery, however, until 1975, when it was discovered entirely by accident (when detaching an angler's float from the river bed at site $\mathrm{A}$ in Fig. 1) that the 'bedrockformed' river bed was in fact made up of tightly packed layers similar to those found on the point bars downstream. In view of the earlier pollen results and of their position as the lowermost deposit on the valley floor, the first superficial reaction was to class these as being of possible preglacial origin. When this matter was brought up at a meeting of re- 


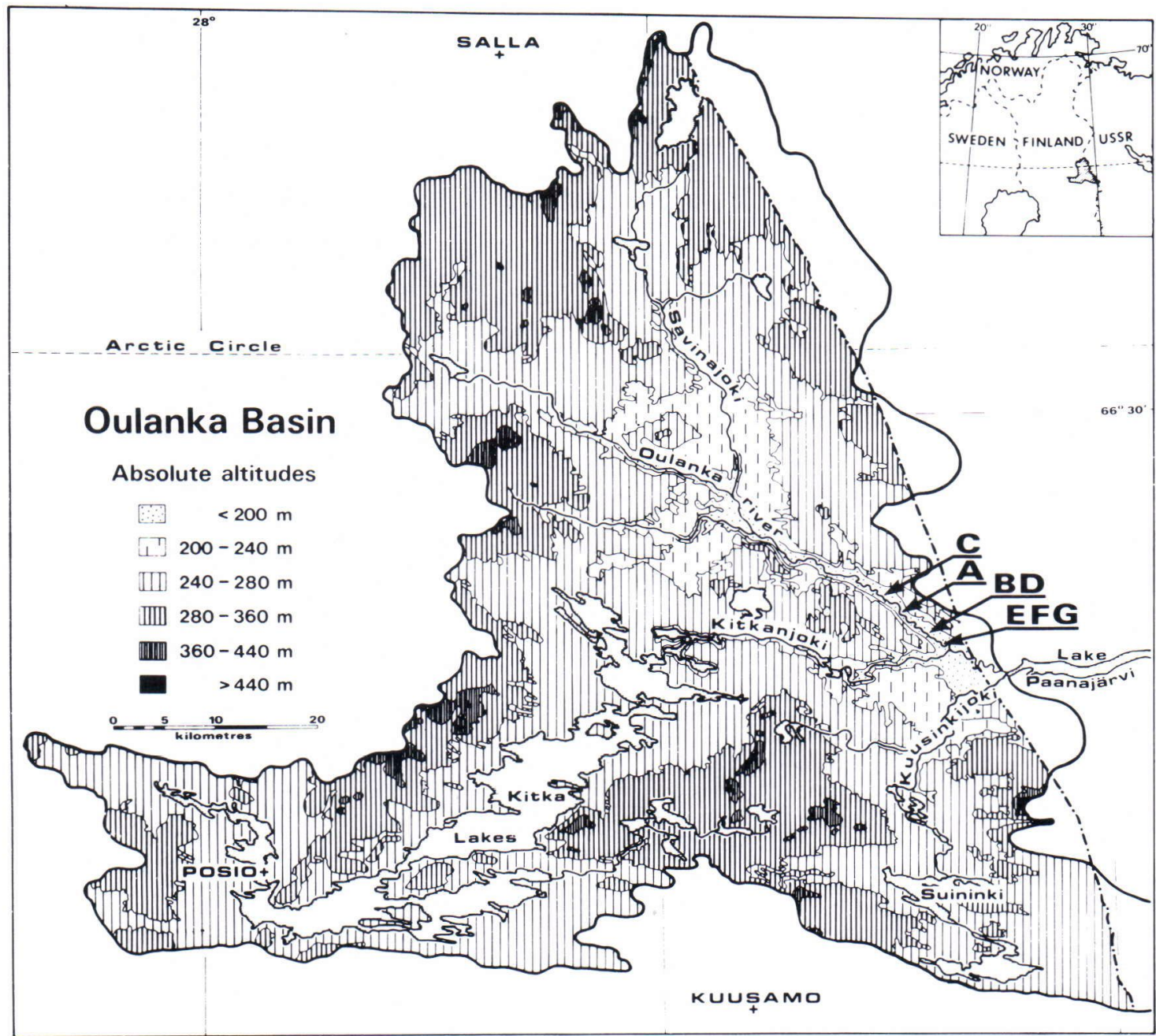

Fig. 1. Location of the sites studied $(\mathrm{A}-\mathrm{G})$ in the catchment area of the Oulanka river.

search scientists working in the Kuusamo area in 1978, Dr. Ahti Silvennoinen of the Geological Survey of Finland announced that the same ideas had occurred to him when he had made similar observations in the late 1960's. Corresponding deposits have since been found with certainty at seven sites on the lower course of the Oulanka river during research connected with IGCP-project No. 158(A). Pollen analyses have now been carried out on seven of the samples, which were obtained by diving or digging, and radiocarbon dates are now available for three of them. These sites form the basis for the discussion to be entered into here, in which all the dates referred to are expressed in radiocarbon years.

\section{Background events}

With very few exceptions (see Hirvas \& Tynni, 1976, pp. 35-37), the Pleistocene glaciations may be said to have destroyed all the pre-Quaternary deposits in Finland, and the same fate may also be assumed for the majority of the deposits pre-dating the last, 

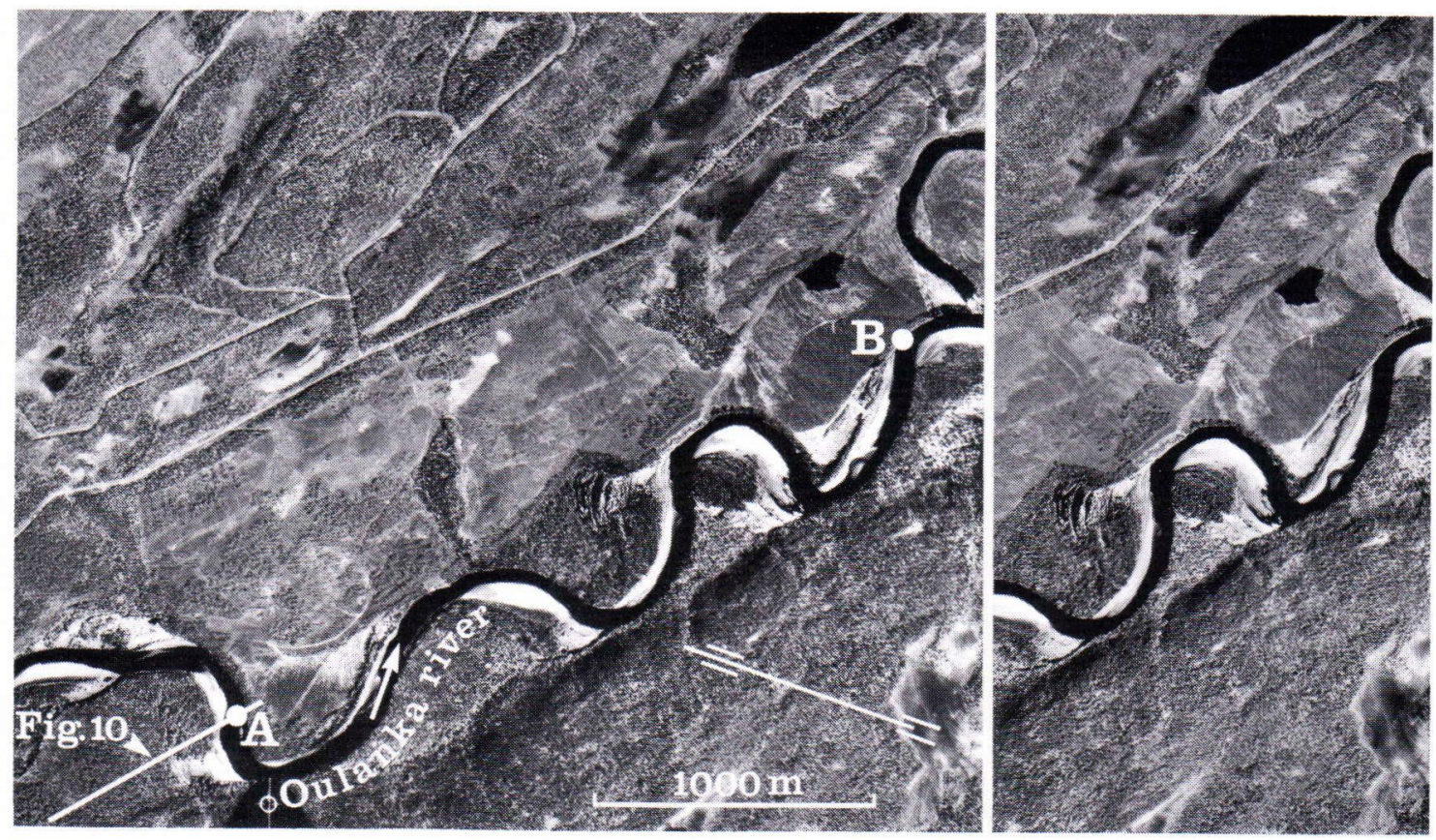

Fig. 2. Partly stereoscopic areal view of the lower course of the Oulanka valley (photographs 89182/9-10. Sites A-B show the locations of the deposits and profiles depicted in Figs. 3-7 and 10. Photographed in 1980. By permission of Topografikunta.

or Weichselian (Würmian or Baltic) glaciation, although numerous finds have been reported over the last ten years, especially in the north of Finland, which would point to horizons originating from either the Eemian Interglacial, approx. 120000 B.P., or one of the stages of the Middle Weichselian Interstadial. Within these Betula and Pinus alternate as the dominant arboreal species, and in most of which pollen of Alnus, Corylus and Picea is also found (see Korpela, 1969; Hirvas \& Tynni, 1976, pp. 37-39; Forsström \& Peuraniemi, 1977, p. 11; Aario \& Forsström, 1979, pp. 37-39 and literature cited therein; Hirvas et al., 1981).

According to the picture of events which has become established in recent times, the ice of the Weichselian glaciation had receded to about the latitude of the Arctic Circle on the eastern border of Finland by about 9500 B.P. and had reached a point corresponding to the present watershed in the west by about 150-200 years after this (Hyvärinen, 1973, p. 93; Heikkinen \& Kurimo, 1977, pp. 20-21; Aario \& Forsström, 1979, pp. 39-44; Koutaniemi, 1979, pp. 39-42; Kurimo, 1979, pp. 58-59; Punkari 1979, pp. 25-27; Saarnisto, 1981 , pp. $20-21$ ). At this time the Oulanka valley, which lay about $100 \mathrm{~m}$ below the surrounding terrain, served as a collector channel for meltwater from extensive parts of southern Salla and northern Kuusamo (Fig. 1). This led to the deposition of vast quantities of silt, sand and gravel, some subaquatic in origin and some supra-aquatic, on the valley floor, regulated by the water level prevailing in the valley at that time (160-170 $\mathrm{m}$ a.s.1.). Considerable amounts of ice were also buried beneath these deposits (Koutaniemi, 1979 , pp. 21-28, 44-45). The rapid process of land uplift which began upon the emergence of the land from beneath the ice and the consequent tilting of the earth's crust towards the east forced the waters to 

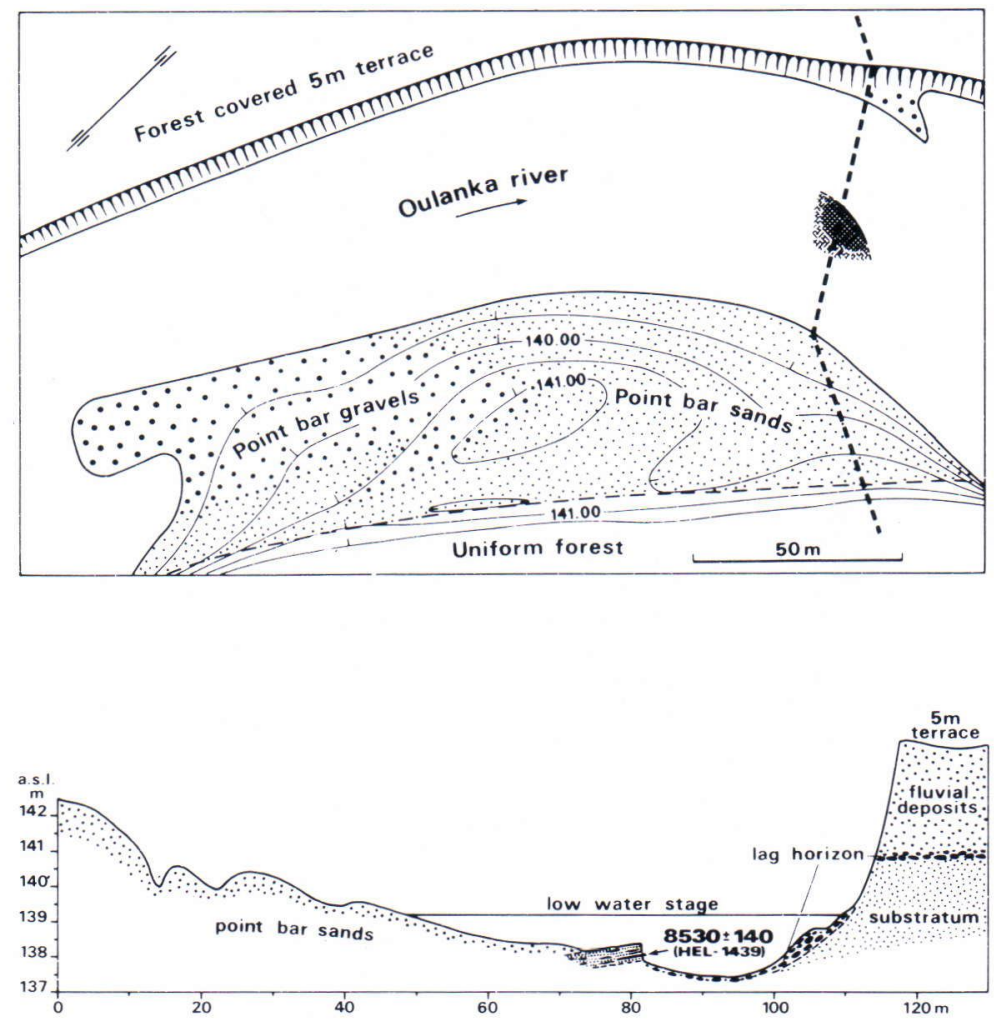

Fig. 3. Location of the deposit at Kallioperä (shaded in the channel) in relation to its environment (site A in Figs. 1 and 2). The broken line indicates the course of the profile in Fig. 4.

Fig. 4. Cross-section of the deposit at Kallioperä (site A; see Figs. 1-3). For further details, see text. flow out of the valley in that direction, reduced the base level of erosion and set in motion a process of reorganization of the glaciofluvial valley fill material under the combined influence of lateral and vertical erosion which has been typical of the development of the valley during the postglacial period. One stage in this is depicted in Fig. 2.

\section{Occurrence of organic deposits}

\section{Site A, Kallioperä}

At this point the river has cut down about $25 \mathrm{~m}$ into the valley fill material and the whole of the valley floor has become a field of variable fluvial landforms as a result of meandering (Fig. 2). There is a river terrace $5 \mathrm{~m}$ in height and several thousands of years old directly opposite the site (Koutaniemi, in press) and point bar sands dating from recent centuries on the inside of the bend. The channel of the river is in a more or less stable state at the present time, but the inside of the bend is reshaped every years as the spring high waters carry off and redeposit some of the sand (Figs. 2 and 3).

The organic deposits lie at a depth of $1-1.5 \mathrm{~m}$ and are visible on the river bed in an area of about one acre (coordinates $\mathrm{x}=$ $7358.83, y=479.44)$. Research carried out by diving and by means of a hand-operated percussion drill with a sampling tip (Partner) has shown the deposits to continue beneath the sands of the point bar in a slab of more or less the same thickness as is visible in the vertical section in the centre of the channel (Fig. 4). No organic material was found in the undercut slope on the outer wall of the channel. 
The material of this find is characterized by parallel lamination, with the whole formation sloping gently in a direction close to the longitudinal axis of the valley to pass under the point bar (Fig. 4). The silt and fine sand contains an admixture of plant remains and wood fragments, often in large amounts (Fig. 5 ). The minerogenic fraction is of a very much finer grain size than the middle coarse to coarse sand horizons found above and below it.

A wood fragment recovered from some $20 \mathrm{~cm}$ above the lower boundary of the deposit gave a radiocarbon date of $8530 \pm 140$ B.P. (Figs. 4 and 5), and a sample of material from below this was found to contain $74.7 \%$ Betula pollen, $24.2 \%$ Pinus and $1.1 \%$ Alnus. The arboreal species accounted for $86.4 \%$ of the total pollen, the NAP consisting largely of Cyperaceae $(67.8 \%)$.

\section{Site B, Alaniemi}

At this site the organic material was found beneath sediments which had slipped down to the base of the undercut slope opposite the Alaniemi meander headland (Figs. 2 and 6 ; coordinates $\mathrm{x}=7357.06, \mathrm{y}=481.53$ ), and was overlain by some $4 \mathrm{~m}$ of fluvial deposits

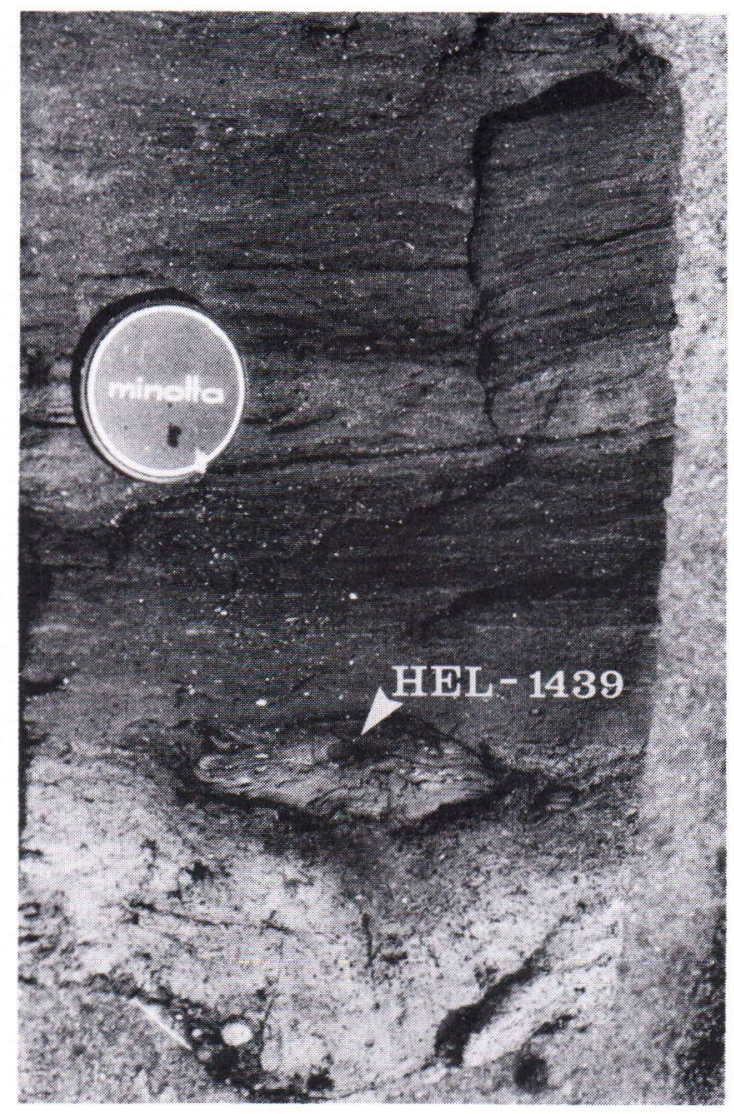

Fig. 5. Vertical section through the old deposits at Kallionperä. The date HEL-1439 (see Fig. 4) applies to the wood fragment in the picture. Photographed by the author on 7 th July, 1980.

Fig. 6. General view of the undercut slope opposite to Alaniemi (site B in Figs. 1 and 2) at the foot of which organic material was found close to the water level (black arrow). Photographed by the author on 4th July, 1980.

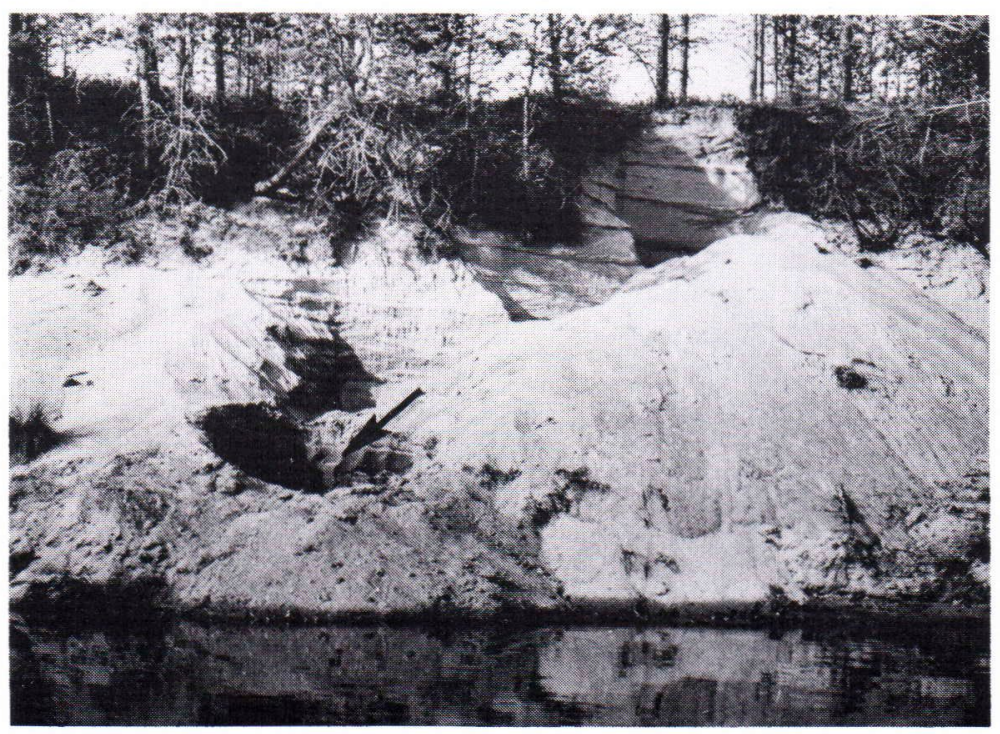


composed, typically for a meandering river, of a coarse lag horizon covered by crossbedding sands of the point bar facies with two intervening erosion pavements and finally weakly horizontally laminated topstratum horizons (cf. Allen, 1965a, pp. 129153; Reineck \& Singh 1975, pp. 238-240; Gullentops \& Paulissen, 1978, pp. 28-29). Below the organic material and running weakly in parallel to it is a bed of laminated coarse sand with some still coarser fractions (Fig. 7).

The tightly packed, black-coloured bed of organic and minerogenic material some $25 \mathrm{~cm}$ in thickness is homogeneous to the extent that it does not present any obvious stratification. The whole bed slopes gently across the valley in a north-easterly direction (cf. Figs. 2 and 7). A sample of plant remains extracted from the minerogenic material for radiocarbon dating gave a result of $8600 \pm 150$ B.P. The arboreal pollen spectrum for the deposits comprised Betula (71.1\%) and Pinus (28.9\%), which together accounted for $72.8 \%$ of the total pollen flora. The most common NAP taxa were Cyperaceae $(22.6 \%)$ and Gramineae $(30.6 \%)$ :

\section{Site C, Antinniemi}

This site was discovered in connection with the study of an $8 \mathrm{~m}$ river terrace (coordinates $\mathrm{x}=7360.65, \mathrm{y}=477.48$ ). The deposits containing organic matter form two horizons at the foot of the bank and slope away rather steeply towards the north extending below the water level of the river (cf. Figs. 1 and 8). Above these is first of all about $4 \mathrm{~m}$ of large-scale cross-bedding foresets of sand, and then a gravel and stoneenriched bed resembling a river channel lag horizon. The upper part of the terrace is composed of cross-bedding and horizontally laminated sands in a sequence more or less typical of deposits accumulating on top of a

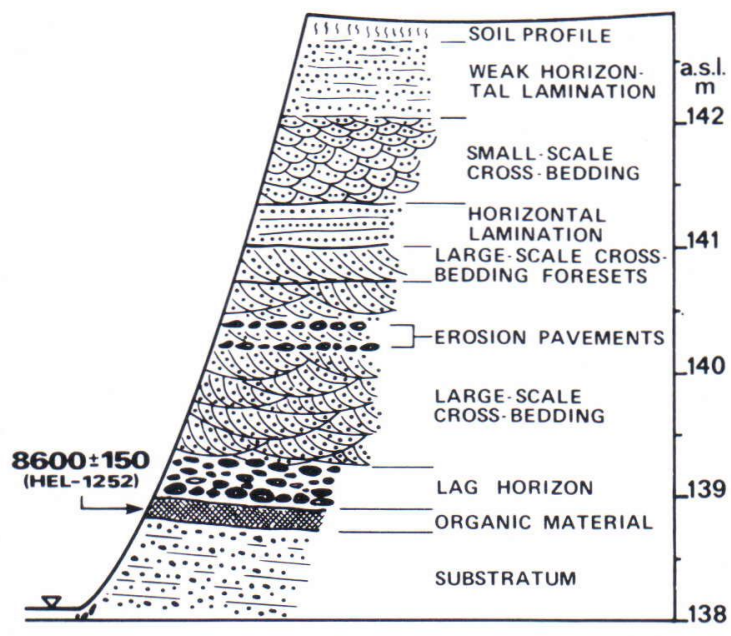

Fig. 7. Stratigraphy of the bank pictured in Fig. 6 (site B in Figs. 1 and 2). For further details, see text.

lag horizon in connection with lateral shift of the river bed (cf. Fig. 8).

Large numbers of well-preserved fragments of tree trunks and other such material can be found in those parts of the organic horizons lying below the waters of the river. One trunk recovered from the lower of the two horizons gave a radiocarbon date of $8730 \pm 170$ B.P. (Fig. 8). The arboreal pollen of this deposit comprised $99 \%$ Betula and $1 \%$ Pinus, and accounted only for $56.2 \%$ of the total pollen. The most common NAP taxa were Rosaceae (45\%) and Gramineae (23\%).

\section{Sites D-G}

The remaining four sites are all located within three kilometres of Alaniemi in a downstream direction (see Figs. 1 and 2). The deposits of site $\mathrm{D}$ were found in the centre of the river bed at a depth of about two metres at the cut-off point of the Siikauopajanlampi oxbow lake (coordinates $\mathrm{x}=7356.87$, $y=481.64)$. The other three are all close to the meander headland of Horsmaniemi (sites E, F and G in Fig. 1). One of these (site $\mathrm{E}$, coordinates $\mathrm{x}=7355.37, \mathrm{y}=483.57$ ) 


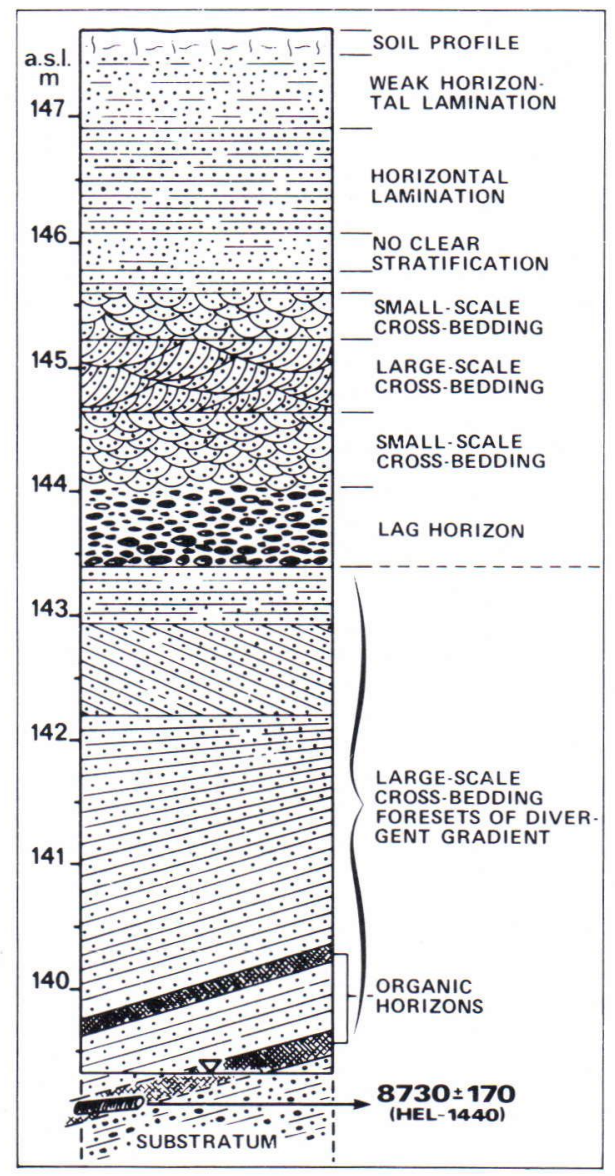

Fig. 8. Location of the organic horizons at Antinniemi (site $\mathrm{C}$ in Fig. 1) in relation to the sediments of the $8 \mathrm{~m}$ river terrace above them. For further details, see text.

lies at the foot of the undercut slope upstream of the headland, and the other two in the bed of the river downstream (site F, coordinates $\mathrm{x}=7355.03, \mathrm{y}=484.00$; site $\mathrm{G}$, coordinates $\mathrm{x}=7355.16, \mathrm{y}=484.16$ ).

The proportions of the principal tree species in the pollen flora at two of these sites, D and F, were rather similar to those at the dated sites described above, with Betula accounting for $75.5-83.9 \%$ of AP and Pinus for 16.1-24\%. Their combined proportions of total pollen varied in the range $38.8-81.6 \%$. At the other two sites, $\mathrm{E}$ and
G, however, Pinus was by far the most common arboreal species $(73.5-82.5 \%)$, while Betula reached only $15-19.5 \%$ and the noble deciduous trees Ulmus, Corylus and Quercus were also represented as well as Alnus (1-5.5\%). Here the AP species amounted to as much as $92.6-93 \%$ of total pollen.

\section{Origins of the organic horizons}

All the deposits for which dates were obtained thus proved to originate from the Holocene, and the same may also be claimed of the other four sites studied only by pollen analysis. With only two exceptions, sites E and $\mathrm{G}$, they would all be located in the Early Boreal Chronozone (cf. Mangerud et al., 1974, p. 122), although sites D and F could possibly be regarded as belonging equally well to the Late Preboreal Chronozone. The deposits at sites $\mathrm{E}$ and $\mathrm{G}$ are derived from a time when pine forests were dominant, and are thus younger, but even so not younger than 5000 B.P., since no Picea pollen is found in them. All in all, the tree pollen relations and the large amounts of Cyperaceae, Gramineae and Rosaceae among the NAP (except at sites $\mathrm{E}$ and $\mathrm{G}$ ) fit in extremely well with pollen results published for deposits of similar age in north-eastern Finland (see Hyvärinen, 1972, pp. 9-15; Vasari, 1974, pp. 108-114; Hicks, 1975, pp. 8-16; Koutaniemi, 1979 , pp. 40-41).

The crucial question as far as the origins of the organic deposits are concerned is naturally whether they were laid down in situ or not. Before the discovery of the Antinniemi deposit, when those at Kallioperä, for instance, were already known to be postglacial in origin, one was inclined to favour the theory that these slabs were derived from some mire area further upstream. The assumption was that they had become frozen fast to the ice on the river bank at various times over the millenia and been transported 


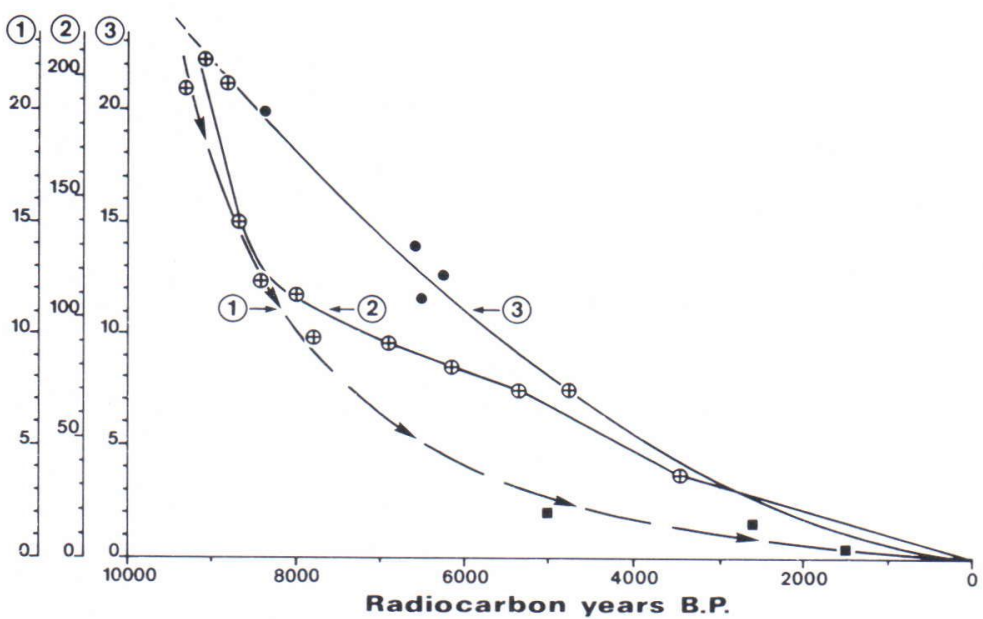

Fig. 9. Rate of postglacial downcutting on the lower reaches of the Oulanka and Kitkanjoki valleys (1) (Koutaniemi \& Ronkainen 1982, fig. 2) in relation to shoreline displacement, i.e. the fall in the base level of erosion in the Peräpohjola region (2) (Saarnisto, 1981, fig. 9) and tilting on the ancient shoreline of Kitkanjärvi (3) (see Fig. 1; Heikkinen \& Kurimo 1977, fig. 16). The similarity between curves 1 and 2 is striking, even though the latter does begin its fall slightly later than the former, for obvious reasons. The vertical scales in metres for curves 1 and 2 and in $\mathrm{cm} / \mathrm{km}$ for 3 are marked on the left.

downstream by the ensuing flood waters. Such a theory would fit very well with all the finds except for that at Kallioperä, where even those deposits which were visible were obviously too large to have been carried downstream by ice floes.

As at the other sites, the subsequent underwater investigations carried out by the author at Antinniemi brought up an entirely new aspect regarding the origin of the deposits concerned, in the sense that the organic horizons at this site were shown to continue across the river channel as a curving formation running beneath the sands of the point bar on the inside of the bend. Since they also dipped steeply below the lag horizon even in the river bed, one was left in no doubt that they must have been laid down in situ. In view of the similarities between the deposits and their stratigraphic positions, this situation may then be said to apply equally well to all the sites.

In the light of the above, the deposits concerned may be interpreted as representing the basal horizons of either palaeochannels or kettle-holes. As has been shown by research carried out on the lower reaches of the Oulanka and Kitkajoki rivers, downcutting, as a consequence of the fall in the base level of erosion following land uplift, was very rapid in early postglacial time, so that the waters of both rivers were flowing at levels only a couple metres above the present river bed by 5000 B.P. (Fig. 9). It does not seem at all likely, however, that the rivers could have cut their way down to virtually their present levels during the first thousand years after the ice retreat, as the dates obtained for the organic material would seem to suggest (see Koutaniemi \& Ronkainen, 1982; Koutaniemi, in press).

The deposits must therefore be derived from old kettle-holes. There are indeed a large number of kettle-holes in the Oulanka valley to testify to the burying of ice blocks in connection with glaciofluvial accumulation, but these are found almost entirely on the upper course of the river (Koutaniemi, 1979, pp. 26-28). The fact that there may have been kettle-holes in the lower reaches of the valley 


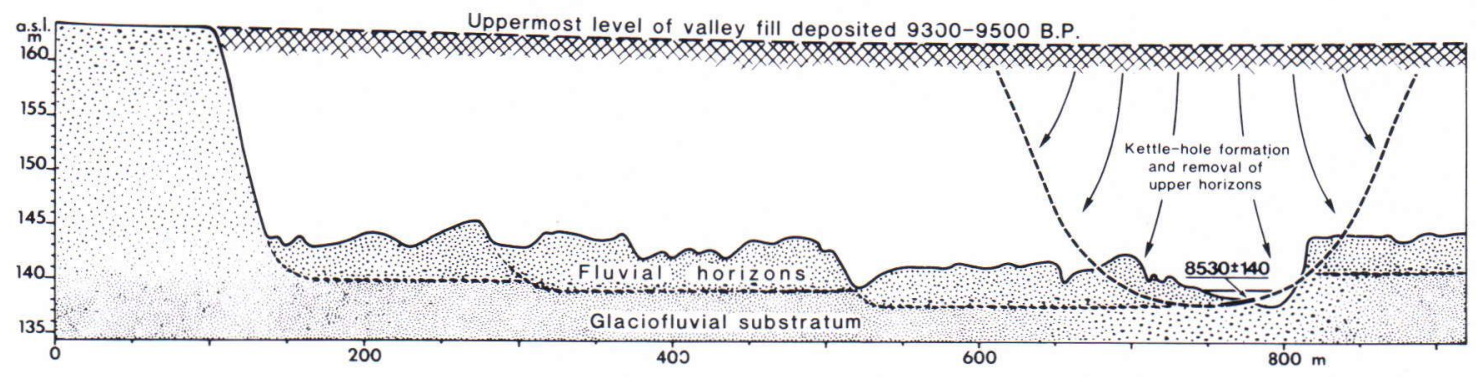

Fig. 10. Cross-section of the Oulanka river valley through the deposit at Kallioperä (see Figs. 1-4) and schematic representation of the sedimentological consequences of the earlier melting of dead ice at the site.

as well has not really arisen in discussions before, for the simple reason that fluvial erosion has wiped out the kettle-holes themselves (see Koutaniemi, 1979, appendices IV-VII) and that the origin of the present organic deposits has been uncertain.

The fact that these deposits originated from kettle-holes also explains one stratigraphical oddity attached to all the finds, as illustrated in Fig. 10. The glaciofluvial material lying beneath the fluvial deposits close to the present-day water level in the Oulanka river normally belongs to the bottom set beds of the valley fill (Koutaniemi, 1980, fig. 3) and is usually composed of silt or very fine sand (Koutaniemi, 1981, p. 95), whereas the material found beneath the kettle-hole deposits, which lies at the same level, as noted above, is without exception the same middle coarse and coarse sand that can be found in the corresponding residues of the topset beds of the valley fill remaining on the sides of the valley (see Koutaniemi, 1979, p. 31). This receives a natural explanation if one assumes that the deposits had been removed in connection with the kettle-hole formation (cf. Fig. 10).

The Oulanka river terraces usually contain 4-5 $\mathrm{m}$ of fluvial sediments (Koutaniemi, 1981, fig. 5 ; in press, figs. 4 and 7 ), and the location of the kettle-hole deposits beneath the lag horizon, as seen at Alaniemi (see Fig. 7) is a logical outcome of the erosion and deposi- tion brought about by the lateral movements in the river channel. The deposits at Antinniemi differ in their stratigraphic location (see Fig. 8), however, since the stratigraphy of the $8 \mathrm{~m}$ terrace indicates that deposition of the $4 \mathrm{~m}$ or so of surface horizons occurred in the sediment facies mode characteristic of the terraces of the Oulanka valley. But where do the almost $4 \mathrm{~m}$ of sand deposits occupying the lower part of the terrace and overlying the organic horizons originate from?

When considering these sands, it should be remembered at the outset that at the time when the organic deposits in the kettle-hole were buried, the Oulanka river must have been flowing past this site at least at the height required to create the present $8 \mathrm{~m}$ terrace, i.e. about $5 \mathrm{~m}$ above its present level. It is even possible that they were buried at an earlier stage in the lateral movements of the river channel than that at which the $8 \mathrm{~m}$ terrace was formed, in which case the water level would have had to have been still higher. Regardless of how this actually took place, however, the kettle-hole must have been able to take shape gradually over many centuries beginning from the accumulation of the valley fill, after which it fell within the scope of fluvial action and forming a deep pool it was filled with large-scale cross-bedded sand laid down in the manner of either delta or sand wave deposits (Fig. 8; cf. Allen, 1965b, pp. 104-105; Whetten et al., 1969, pp. 
1155-1157; Reineck \& Singh, 1975, pp. 238243). The sand horizons found in between the two organic deposits are more likely to have resulted from slope wash or material transported by streams running down the valley sides than from sediments transported by the river itself, since it is improbable that the filling in of the kettle-hole would have been interrupted for any very great length of time once the formation had fallen within the sphere of influence of the river.

It should also be mentioned that a sample of plant remains removed from one slab transported onto the point bar opposite Horsmaniemi (coordinates $\mathrm{x}=7355.08, \mathrm{y}=483.64$ ) by the spring floods gave a radiocarbon date as old as $9500 \pm 220$ B.P. (HEL-988). It is not, of course, impossible that material of this age could have originated from some of the oldest of the kettle-holes, especially when we bear in mind the standard deviation of the radiocarbon date towards a younger interpretation (cf. Koutaniemi, 1979, p. 47), but certain reservations should perhaps be attached to this date, since the sample was in any case not recovered in situ.

\section{Final remarks}

The fact that kettle-holes located in the middle of the valley floor were able to develop undisturbed in such large numbers as would be apparent from the present observations argues strongly for the conclusion that the Oulanka river could not have meandered to anything like its present extent during early postglacial time, for if it had done so, the kettle-holes would have filled with sand within the first few centuries and would never have come to contain deposits of the age shown here by the radiocarbon dates. The change in the flow system of the river would seem to be associated both with climatic factors and very closely with the tilting of the earth's crust, and thus it would seem reasonable to assume that as a consequence of the rapid fall in the base level of erosion at the beginning of the postglacial period, the energy of the river at that stage was chiefly concentrated upon the process of downcutting, and that as the rate of tilting slowed down lateral erosion increased, until the river gradually achieved the situation which prevails at present, in which the role of downcutting appears to be virtually nil (Fig. 9; cf. Koutaniemi, 1979, p. 62).

The finds described above are certainly not the only ones of their kind, and a situation comparable to that an Antinniemi would presumably arise at the present moment, for example, if the river was to shift its course to pass through the kettle-hole represented by Kourulampi (coordinates $\mathrm{x}=7364.46$, $\mathrm{y}=$ 468.80) close to the Oulanka Biological Station. Similarly, new deposits of a corresponding type are likely to come to light in the future as the river changes its course, and could also be found at the present time in other formations which conform to the Oulanka valley in the pattern of their posglacial development.

Acknowledgements. Especial thanks are due to Assoc. Prof. Matti Seppälä of the University of Helsinki and Dr. Antonius M. Winkelmolen of Rijksuniversiteit Groningen for many useful discussions on this topic and for their co-operation in obtaining the radiocarbon date HEL-988. Grateful thanks are also extended to Mr. Heikki Hautala and Miss Maarit Vuopala for their many hours spent on fieldwork in the Oulanka valley, to the Helsinki University Radiocarbon Dating Laboratory for radiocarbon dates and to Mr. Malcolm Hicks for translating the manuscript into English. Financial support from the Finnish Academy of Sciences is gratefully acknowledged. 


\section{References}

Aario, Risto \& Forsström, Lars, 1979. Glacial stratigraphy of Koillismaa and North Kainuu, Finland. Fennia 157, 1-49.

Allen, J. R. L., 1965a. A review of the origin and characteristics of recent alluvial sediments. Sedimentol. 5, 89-191.

Allen, J. R. L., (1965b). Sedimentation to the lee of small underwater sand waves: an experimental study. Jour. Geol. 73, 95-116.

Forsström, Lars \& Peuraniemi, Vesa, 1977. Moreenin alainen orgaaninen kerrostuma Oulaisissa. Geologi 1977, 11.

Gullentops, F. \& Paulissen, E., 1978. Valley sediments. In Thornes J. B. and K. J. Gregory (eds.): Paleohydrological Changes in the Temperature Zone in the Last 15000 Years. Subproject A. Fluvial Environments. Provisional Sub-Project Guide, 23-31. International Geological Correlation Programme, Project No. 158.

Heikkinen, Olavi \& Kurimo, Heikki, 1977. The postglacial history of Kitkanjärvi, North-eastern Finland, as indicated by trend-surface analysis and radio-carbon dating. Fennia 153, 1-32.

Hicks, Sheila, 1975. Variations in pollen frequency in a bog at Kangerjoki, N. E. Finland during the Flandrian. Soc. Sci. Fenn. Commentat. Biol. 80. $28 \mathrm{pp}$.

Hirvas, Heikki, Korpela, Kauko \& Kujansuu Raimo, 1981. Weichselian in Finland before 15,000 B.P. Boreas 10, 423-431.

Hirvas, Heikki \& Tynni, Risto, 1976. Tertiääristä savea Savukoskella sekä havaintoja tertiäärisistä mikrofossiileista. Geologi 1976, 33-40.

Hyvärinen, Hannu, 1972. Flandrian regional pollen assemblage zones in eastern Finland. Soc. Sci. Fenn. Commentat. Biol. 59. 25 pp.

Hyvärinen, Hannu, 1973. The deglaciation history of eastern Fennoscandia - recent data from Finland. Boreas 2, 85-102.

Korpela, Kauko, 1969. Die Weichsel-Eiszeit und ihr Interstadial in Peräpohjola (Nördliches Nordfinnland) im licht von submoränen sedimenten. Ann. Acad. Sci. Fenn. 99. 109 pp.

Koutaniemi, Leo, 1979. Late-glacial and post glacial development of the valleys of the Oulanka river basin, north-eastern Finland. Fennia 157, 13-73.
Koutaniemi, Leo, 1980. Some aspects of the palaeohydrology connected with the development of the relief in the Oulanka river valley, North-eastern Finland, and a review of complementary study concerning IGCP-Project No. 158. Bull. l'Assoc. franc. Quat. 1980, 71-75.

Koutaniemi, Leo, 1981. IGCP-Project No. 158, aims, topics and present-day progress of studies within the sub-project 'Fluvial environment' in Finland. Nordia 15, 91-100.

Koutaniemi, Leo, (in press) Palaeohydrological questions in relation to $\mathrm{C}_{\mathbf{1 4}}$ dating and floodplain deposits in the main rivers of the Oulanka basin. Geol. Jahrb.

Koutaniemi, Leo \& Ronkainen Raimo (1982). Palaeoccurrents from 5000 and 1600-1500 B.P. in the main rivers of the Oulanka Basin, Northeastern Finland. Quat. Stud. Poland 4. (in press).

Kurimo, Heikki, 1979. Deglaciation and early postglacial hydrography in northern Kainuu and Peräpohjola, North-East Finland. A glacial morphological study. Publ. Univ. Joensuu B II 10. $64 \mathrm{pp}$.

Mangerud, Jan, Andersen, Svend T., Berglund, Björn E., \& Donner, Joakim J., 1974. Quaternary stratigraphy of Norden, a proposal for terminology and classification. Boreas 3, 109-127.

Punkari, Mikko, 1979. Skandinavian jäätikön deglasiaatiovaiheen kielekevirrat Etelä-Suomessa (Summary: The ice lobes of the Scandinavian ice sheet during the deglaciation in South Finland). Geologi 31, 22-28.

Reineck, H.-E. \& Singh, I. B., 1975. Depositional Sedimentary Environments. 439 pp. SpringerVerlag. Berlin, Heidelberg and New York.

Saarnisto, Matti, 1981. Holocene emergence history and stratigraphy in the area north of the Gulf of Bothnia. Ann. Acad. Sci. Fenn. A III 130. $42 \mathrm{pp}$.

Vasari, Yrjö, 1974. The vegetation of Northern Finland - past and present. INTER-NORD $13-$ 14, $99-118$.

Whetten, John T, Kelley, James C. \& Hanson, Larry G., 1969. Characteristics of Columbia river sediment and sediment transport. Jour. Sediment. Petrol. 39, 1149-1166.

Manuscript received, April 8, 1982 